\title{
Microbial activity in soil with onion grown in a no-tillage system with single or intercropped cover crops
}

\author{
Monique Souza ${ }^{1}$ (i) Mónica María Machado Vargas ${ }^{2}$ (i) Bárbara Santos Ventura ${ }^{1}$ (i) \\ Vilmar Müller Júnior ${ }^{3}$ Cláudio Roberto Fonsêca Sousa Soares ${ }^{4}$ Cla Claudinei Kurtz $^{5}$ (i) \\ Jucinei José Comin ${ }^{1}$ (i) Paulo Emílio Lovato ${ }^{1^{*}}$ ([)
}

${ }^{1}$ Núcleo de Ensino, Pesquisa e Extensão em Agroecologia, Departamento de Engenharia Rural, Universidade Federal de Santa Catarina (UFSC), Florianópolis, SC, Brasil. E-mail: paulo.lovato@ufsc.br. "Corresponding author.

${ }^{2}$ Grupo de investigación Salud y Sostenibilidad, Escuela de Microbiología, Universidad de Antioquia, Medellín, Colombia. ${ }^{3}$ Instituto Federal do Paraná, Campo Largo, PR, Brasil.

${ }^{4}$ Departamento de Microbiologia, Imunologia e Parasitologia, Universidade Federal de Santa Catarina (UFSC), Florianópolis, SC, Brasil. ${ }^{5}$ Estação Experimental de Ituporanga, Empresa de Pesquisa Agropecuária e Extensão Rural de Santa Catarina, Florianópolis, SC, Brasil.

ABSTRACT: Microbial biomass is a driving force in the dynamics of soil organic matter, and microbial activity is an indicator of soil quality in agroecosystems, reflecting changes in management practices and environmental conditions. We evaluated the effect of monoculture and intercropped winter cover crops on soil chemical attributes, microbial biomass carbon (MBC), basal respiration (BR), metabolic quotient (qCO $)$, urease, $\beta$-glucosidase, and fluorescein diacetate (FDA) hydrolysis activity, as well as onion yield in a no-tillage system. Soil is a Typic Humudept, and treatments were control with spontaneous vegetation, barley, rye, oilseed radish (OR), OR + rye, and OR + barley. The soil was sampled $(0-10 \mathrm{~cm})$ five times between June and December. There were no differences among treatments for MBC and BR, and the highest values for those attributes occurred in June, when cover plants were in their initial stage. Although, qCO, was not affected by any treatment, it varied among sampling periods, ranging from 0.62 to $10 \mu \mathrm{g} \mathrm{C}-\mathrm{CO} \mathrm{mg}^{-1} \mathrm{MBC} \mathrm{h}^{-1}$, indicating a low-or no stress environment. Cover crops had little influence on enzyme activity, but FDA was lowered in areas with single crops of barley and rye. Average onion yield in cover crops treatments was $13.01\left(\mathrm{Mg} \mathrm{ha}^{-1}\right)$, 30-40\% higher than in the control treatment.

Key words: biological activity, cover crops, green manure, Allium cepa L.

Atividade microbiana em solo com cebola cultivada em sistema de plantio direto com plantas de cobertura solteiras ou consorciadas

RESUMO: A biomassa microbiana é determinante na dinâmica da matéria orgânica do solo e sua atividade é um indicador de qualidade do solo em agroecossistemas, refletindo mudanças em práticas de manejo e em condições ambientais. Avaliou-se o efeito de culturas de cobertura de inverno, solteiras ou consorciadas, sobre atributos químicos do solo, carbono da biomassa microbiana (CBM), respiração basal $(R B)$, quociente metabólico ( $q C O_{2}$ ) e atividade das enzimas urease, $\beta$-glucosidase e FDA, bem como o rendimento da cebola em um sistema de plantio direto. O solo é um Cambissolo Húmico alumínico, os tratamentos foram testemunha com vegetação espontânea, cevada, centeio, nabo forrageiro (NF), NF + centeio e NF + cevada. Realizaram-se cinco coletas de amostras de solo (0-10 cm) entre junho a dezembro. Não houve diferenças entre os tratamentos para $C B M$ e RB, e os maiores valores para esses atributos ocorreram em junho, quando as plantas de cobertura estavam em seu estágio inicial. Embora o $q \mathrm{CO}_{2}$ não tenha sido afetado por nenhum tratamento, ele variou entre os periodos de amostragem, com valores entre 0,62 e $10 \mu \mathrm{g}$ de C-CO $\mathrm{mg}^{-1} \mathrm{MBC} \mathrm{h}^{-1}$, indicando um ambiente de baixo ou nenhum estresse. As culturas de cobertura tiveram pouca influência na atividade enzimática, mas o FDA foi reduzido em áreas com cultivos solteiros de cevada ou centeio. $O$ rendimento médio de cebola nos tratamentos com culturas de cobertura foi de 13,01 (Mg ha $\left.\mathrm{M}^{-1}\right)$, mais alto que no tratamento controle. Palavras-chave: atividade microbiana, plantas de cobertura, adubação verde, Allium cepa.

\section{INTRODUCTION}

Onion is an important crop in Brazil, and the state of Santa Catarina is one of the leading production regions (EPAGRI, 2013). In this region, onions are grown under conventional management system, which involves plowing and harrowing at planting, causing physical, chemical and biological degradation (MARINARI et al., 2006; LOSS et al., 2015). Also, this cultivation 
system has enhanced water and nutrient losses due to erosion and indiscriminate use of fertilizers and herbicides to control weeds (PANACHUKI et al., 2011). Alternatively, onion and other vegetables have been grown in an agroecological no-tillage system without the use of pesticides and soluble mineral fertilizers (SPDH, for Sistema de Plantio Direto de Hortaliças). The system follows ecological principles of management, such as soil mobilization restricted to planting lines, different cover crops species, and split fertilizer applications (WEZEL et al., 2014; MIGLIORINI \& WEZEL, 2017). We seek to reduce, even eliminate, the use of chemical control, replacing it with the physical barrier created by plant residues on the soil surface. A high amount of plant biomass, as well as cover crop diversity, will also improve soil chemical and biological attributes.

Cover crops residues increase soil organic matter; and consequently, cation exchange capacity (CEC), enhancing adsorption of elements such as calcium $(\mathrm{Ca})$ and magnesium $(\mathrm{Mg})$, and complexation of potentially harmful elements, such as aluminum (Al) (OLIVEIRA et al., 2016). In addition, those plants can uptake nutrients from deeper soil layers, such as phosphorus (P) and potassium (K). Upon mineralization, those nutrients accumulated in plant tissues are released in topsoil layers (BASSEGIO et al., 2015; HUBBARD et al., 2013; OLIVEIRA at al., 2016). Cover crops are also a source of $C$, increasing soil organic matter, stimulate soil microbial populations, improve soil aggregation, and create habitats for diverse soil organisms (RAMOS et al., 2010). Soil organic matter also stores $\mathrm{N}$ in organic forms and mineralize it and make it available to plants (LOSS et al., 2015). The main driving force of soil organic matter is its microbiota; and consequently, soil biological properties may be indicators of soil quality. A strong reason to evaluate soil quality is to assess the effects of soil management practices in the long term and to predict soil degradation processes, in order to prevent or remediate degradation. Therefore, soil quality indicators should be sensible to changes in the short or medium term (MARTINEZ-SALGADO et al., 2010). Microbial biomass and its activity are important indicators of soil quality in agroecosystems, as they respond to differences in management practices (MARINARI et al., 2006; BENINTENDE et al., 2008) and to environmental stress (BENINTENDE et al., 2008). Soil basal microbial respiration is used to monitor residue decomposition because it varies due to changes in soil substrate availability, moisture, and temperature (MOREIRA \& SIQUEIRA, 2006). The metabolic quotient $q \mathrm{CO} 2$, the ratio between soil microbial respiration and biomass, is another indicator of environmental stress on soil microbial population (MERCANTE et al., 2008; ANDERSON \& DOMSCH, 2010). The activities of different soil enzymes are indicators of microbial activity, since they are sensitive to short-term changes in the soil, and point to specific metabolic activities, related to nutrients or substrates present in the soil (RAMOS et al., 2010).

Understanding the dynamics of nutrient release and biological activity in agroecological systems using soil cover crops, as is the case of the no-tillage vegetable production system, will allow the development and adoption of soil management strategies. It will also help to evaluate how different cover crop species contribute to soil microbial activity and; consequently, to sustainable onion production, as relatively few studies have evaluated soil microbial activity in systems without the use of pesticides and soluble mineral fertilizers. This research aimed to evaluate the influence of winter cover crops on chemical and biological soil attributes in an area with onion grown in a no-tillage system.

\section{MATERIALS AND METHODS}

The experiment was carried out in Ituporanga, Southern Brazil $\left(27^{\circ} 22^{\prime} \mathrm{S}\right.$ and $49^{\circ} 35^{\prime}$ $\mathrm{W}, 475 \mathrm{~m}$ altitude), an area with a humid subtropical climate (Köppen's Cfa, $17.6{ }^{\circ} \mathrm{C}$ mean annual temperature and $1430 \mathrm{~mm}$ annual rainfall) (KÖPPEN \& GEIGER, 1936). Mean temperature and rainfall during the experiment are presented in figure 1 . The soil is a Humic Dystrudept (SOIL SURVEY STAFF, 2010)), with the attributes described in table 1.

The experiment was implemented in an area with a previous 20-year history of onion crops in conventional tillage system (plowing, disc harrowing, and rototilling). Between 1996 and 2007, a minimum cultivation system was used for onion production in rotation with cover crops: black oat (Avena strigosa Schreb), velvet bean (Mucuna aterima Piper \& Tracy), millet (Pennisetum glaucum L.), sunn hemp (Crotalaria juncea L.), and vetch (Vicia sativa L. The area had sweet potatoes (Ipomoea batatas (L.) Lam.) until 2009, when the no-tillage system experiment was implemented. At the beginning of the experiment (April 2009), the area was desiccated with glyphosate, and lime was applied and incorporated to increase $\mathrm{pH}$ in water to 6.0. After that, no synthetic agrochemicals or mineral fertilizers were used.

The six treatments were: (i) control (fallow); (ii) black oats (Avena strigosa L.) (120kg seeds ha-1); (iii) rye (Secale cereale L.) (120kg seeds 


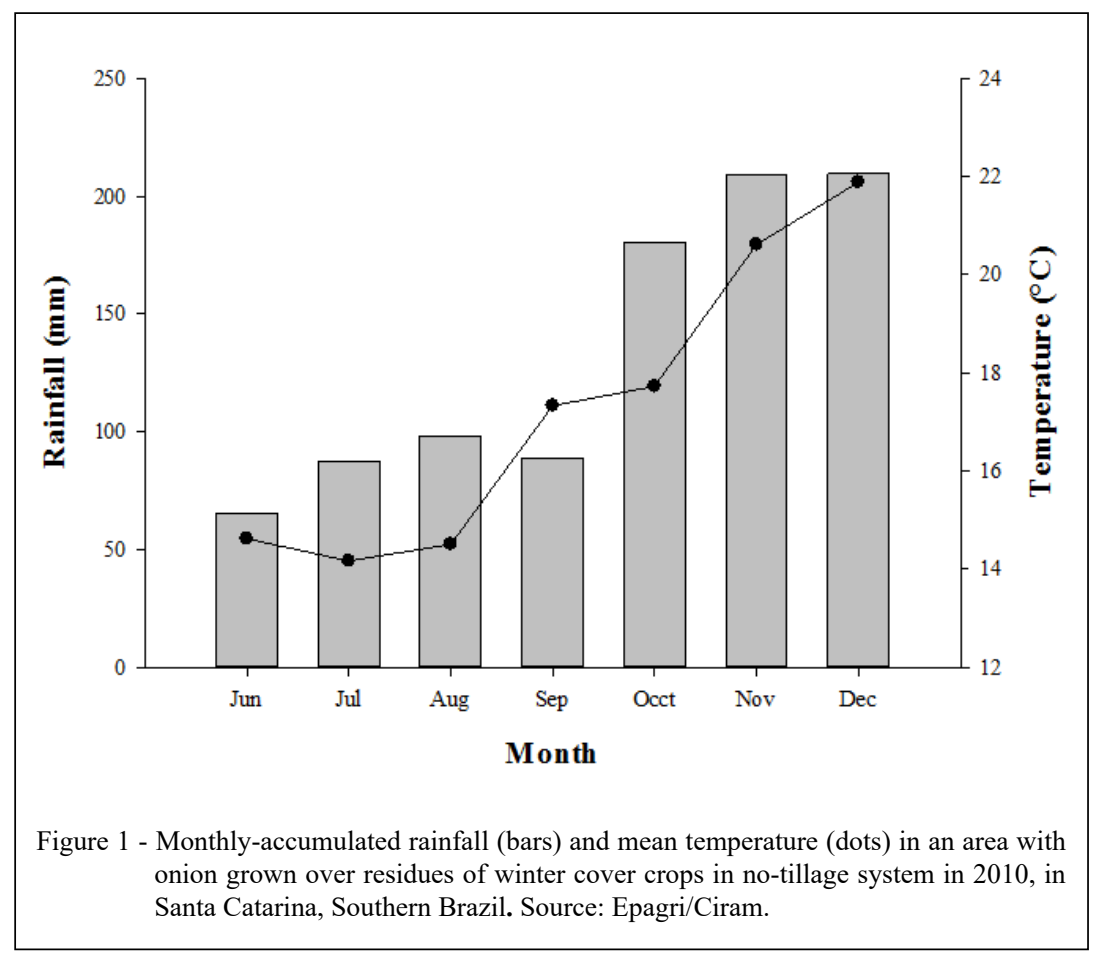

ha $\left.^{-1}\right)$; (iv) oilseed radish (Raphanus sativus L.) (20 $\mathrm{kg}$ seeds ha $\left.{ }^{-1}\right) ;(\mathrm{v})$ oilseed radish + rye $(10+60 \mathrm{~kg}$ seeds ha $\left.{ }^{-1}\right)$, and (vi) oilseed radish + black oats $(10+$ $60 \mathrm{~kg}$ seeds ha- ${ }^{-1}$. Treatments were arranged in blocks, with eight replicates per treatment. Each plot had 25 $\mathrm{m}^{2}$. In April 2010, cover crops were sown again, and barley (Hordeum vulgare L.) replaced black oats. All seeds were broadcast on the soil surface, and a seed drill was passed twice on each plot to ensure that most seeds would move from the litter to the soil surface. Seed doses were 1.5 times the values recommended for the region (MONEGAT, 1991). In July 2009 and July 2010, all plots were knife-rolled and received $96 \mathrm{~kg} \mathrm{P} \mathrm{ha}^{-1}$ (Gafsa rock phosphate), plus poultry litter $\left(5.0 \mathrm{~m}^{3}\right)$ with $175 \mathrm{~kg} \mathrm{~d} \mathrm{P} \mathrm{ha}^{-1}, 125 \mathrm{~kg} \mathrm{~K} \mathrm{ha}^{-1}$, and $100 \mathrm{~kg} \mathrm{~N} \mathrm{ha}^{-1}$. Half of the poultry litter was applied at transplanting the onion seedlings and a half after 30 days. A no-tillage seed drill opened furrows for onion plantlets (cv. 'Empasc 352' - Bola Precoce). In both years, onion plants were placed manually, 0.10 $\mathrm{m}$ apart in each line, with $0.40 \mathrm{~m}$ between lines, with 10 onion lines per plot. Manual weeding was done in 2009 e 2010 at 40 and 90 days after transplanted of onion seedlings to reduce the number of weeds.

In June 2010 , ten $0-0.10 \mathrm{~m}$ deep soil subsamples were collected in each plot. Soil samples were air-dried, sieved (2-mm mesh), and analyzed.
Organic matter (OM) was estimated by the WalkleyBlack method (EMBRAPA, 1997); soil $\mathrm{pH}$ was measured in a $1: 1(\mathrm{v} / \mathrm{v})$ soil: water suspension. After extraction with Mehlich 1 solution $(0.05 \mathrm{~mol}$ $\mathrm{L}^{-1} \mathrm{HCl}+0.0125 \mathrm{~mol} \mathrm{~L}^{-1} \mathrm{H}_{2} \mathrm{SO}_{4}$ ), available $\mathrm{P}$ and exchangeable $\mathrm{K}$ were measured by spectrophotometry and flame photometry, respectively (TEDESCO et al., 1995). After extraction (1-mol L ${ }^{-1} \mathrm{KCl}$ solution), exchangeable $\mathrm{Ca}$ and $\mathrm{Mg}$ were determined by Atomic Absorption Spectrometry. Exchangeable $\mathrm{Al}$ was determined by titration with $\mathrm{NaOH} 0.0125 \mathrm{~mol}$ $\mathrm{L}^{-1}$ (TEDESCO et al., 1995). Cation exchange capacity at $\mathrm{pH} 7.0\left(\mathrm{CEC}_{\mathrm{pH} 7.0}\right)$ was calculated as the sum of exchangeable bases $(\mathrm{Ca}+\mathrm{Mg}+\mathrm{K})$ plus the estimated $\mathrm{H}+\mathrm{Al}$ (CQFSRS/SC, 2004).

Ten soil subsamples $(0-10 \mathrm{~cm})$ were collected in June, July, August, November, and December 2010 for microbiological analyses. Samples were sieved $(2 \mathrm{~mm}$ mesh), plant residues were removed manually, soil moisture was adjusted to $60 \%$ of field capacity, and the samples were stored at $4{ }^{\circ} \mathrm{C}$ for 10 days. Samples collected in June and December were used to assess enzyme activity. FDA was measured by spectrophotometry (DICK et al., 1996), and urease activity was estimated by quantification of ammonia released after soil incubation with a urea solution (TABATABAI \& 
Table 1 - Soil chemical attributes (0-10 cm layer) and onion bulb yield in area with residues of winter cover crops single or intercropped in no-tillage system, 2010, Santa Catarina, Southern Brazil.

\begin{tabular}{|c|c|c|c|c|c|c|c|c|c|c|}
\hline Cover crop & Organic matter & $\mathrm{pH}_{\mathrm{H} 2 \mathrm{O}}$ & $\mathrm{P}$ & $\mathrm{K}$ & $\mathrm{CEC}_{\mathrm{pH} 7.0}$ & $\mathrm{Mg}$ & $\mathrm{Ca}$ & $\mathrm{S}$ & V & Onion yield \\
\hline & $\mathrm{g} \mathrm{Kg}^{-1}$ & & \multicolumn{2}{|c|}{-----mg dm ${ }^{-3}$------ } & \multicolumn{4}{|c|}{-------------cmol $\mathrm{dm}^{-3}$------------- } & $\%$ & $\mathrm{Mg} \mathrm{ha}^{-1}$ \\
\hline Control & $36.4 a^{*}$ & $5.7 \mathrm{a}$ & $60.6 \mathrm{a}$ & $437 c$ & $14.5 \mathrm{a}$ & $3.0 \mathrm{a}$ & $5.6 \mathrm{a}$ & $9.7 \mathrm{a}$ & $66.3 b$ & $9.6 \mathrm{~b}$ \\
\hline Barley & $36.6 \mathrm{a}$ & $5.6 \mathrm{a}$ & $64.0 \mathrm{a}$ & $395 d$ & $14.2 \mathrm{a}$ & $2.9 \mathrm{a}$ & $5.4 \mathrm{a}$ & $9.3 b$ & $65.4 \mathrm{~b}$ & $12.8 \mathrm{a}$ \\
\hline Rye & $36.8 \mathrm{a}$ & $5.7 \mathrm{a}$ & $62.7 \mathrm{a}$ & $461 b$ & $14.7 \mathrm{a}$ & $3.0 \mathrm{a}$ & $5.8 \mathrm{a}$ & $9.9 \mathrm{a}$ & $67.2 b$ & $12.5 \mathrm{a}$ \\
\hline Oilseed & $36.9 \mathrm{a}$ & $5.8 \mathrm{a}$ & $66.1 \mathrm{a}$ & $468 b$ & $14.6 \mathrm{a}$ & $3.0 \mathrm{a}$ & $5.8 \mathrm{a}$ & $9.9 \mathrm{a}$ & $68.5 \mathrm{a}$ & $13.5 \mathrm{a}$ \\
\hline \multicolumn{11}{|c|}{ - - } \\
\hline OR + Barley & $37.4 \mathrm{a}$ & $5.8 \mathrm{a}$ & $64.7 \mathrm{a}$ & $508 \mathrm{a}$ & $14.7 \mathrm{a}$ & $3.1 \mathrm{a}$ & $5.7 \mathrm{a}$ & $10.1 \mathrm{a}$ & $68.6 \mathrm{a}$ & $13.4 \mathrm{a}$ \\
\hline OR + Rye & $38.4 \mathrm{a}$ & $5.7 \mathrm{a}$ & $74.2 \mathrm{a}$ & $442 c$ & $14.9 \mathrm{a}$ & $3.0 \mathrm{a}$ & $5.8 \mathrm{a}$ & $9.97 \mathrm{a}$ & $66.9 \mathrm{~b}$ & $13.3 \mathrm{a}$ \\
\hline
\end{tabular}

${ }^{*}$ Means followed by the same letter in each column do not differ by the Scott-Knott test $\left.\mathrm{P} \leq 0.05\right)$. CEC $=$ Cation exchange capacity; $\mathrm{S}=$ Sum of bases; $\mathrm{V}=$ base saturation.

BREMNER, 1972). The $\beta$-glucosidase activity was quantified as $\rho$-nitrophenol released in soil incubated with $\rho$-nitrophenyl- $\beta$-D-glucoside buffer (DICK et al., 1996). Samples collected in June, July, August, November and December were used to measure soil microbial biomass (MBC) by the fumigationextraction method (VANCE et al., 1987), and basal respiration (BR) was evaluated by the incubation method (JENKINSON \& POWLSON, 1976). Metabolic quotient $\left(q \mathrm{CO}_{2}\right)$ was calculated as the ratio between basal respiration and soil microbial biomass. All microbiological measures were done in triplicate, and all results are expressed on a dry soil basis.

All data were submitted to normality (Shapiro - Wilk) and homogeneity (Cochran) tests. The $\mathrm{qCO}_{2}$ data were transformed using square root. Results were subjected to analysis of variance using the SISVAR program and when effects were significant, means were compared using the ScottKnott test $(\mathrm{P}<0.05)$. Significance levels for correlation coefficients between chemical and biological attributes and yield of onion, and between organic matter and chemical attributes were obtained according to Pearson. Principal Component Analysis (PCA) was used for soil chemical attributes $\mathrm{OM}, \mathrm{pH}$ (water), $\mathrm{CEC}_{\mathrm{pH7} .0}, \mathrm{P}, \mathrm{K}, \mathrm{Mg}, \mathrm{Ca}$, as well as the microbiological variables $\mathrm{MBC}, \mathrm{qCO}_{2}, \mathrm{FDA}$, urease activity, and ß-glucosidase activity. Microbiological data were transformed into a single mean value of collected samples. Aiming to minimize data discrepancy, quantitative values were normalized between -1 and 1 using the following equation (HAN et al., 2011):

$v^{\prime}=\frac{2 \cdot[v-\min (v)]}{\max (v)-\min (v)}-$ where $v^{\prime}$ is the normalized value, $v$ is original quantitative value, $\min (v)$ is the minimum value and $\max (v)$ is the maximum value.

\section{RESULTS AND DISCUSSION}

Soil OM, $\mathrm{P}, \mathrm{Mg}, \mathrm{Ca}, \mathrm{pH}_{\mathrm{H} 2 \mathrm{O}}$ and $\mathrm{CEC}_{\mathrm{pH} 7.0}$ did not differ among treatments with single or intercropped cover crops or fallow (Table 1). Exchangeable Al values were null, as expected since soil $\mathrm{pH}$ is above 5.5 in all treatments. Deposition of crop residues on the soil surface over the years helped to maintain OM levels in all treatments (MANFOGOYA et al., 1997), thus eliminating differences in most soil attributes. Besides, application, in all plots, of poultry manure after the cover crop cycle, absence of soil tillage, and low export by onion production contributed to increase OM and CEC (LOURENZI et al., 2016). Soil $\mathrm{pH}$ was affected by the initial liming performed before implementation of the experiment, in addition to the decomposition of crop residues and organic fertilization. Organic materials release organic acids in the soil, which increases adsorption of $\mathrm{H}^{+}$and $\mathrm{Al}^{3+}$, which may result in increase of $\mathrm{pH}$ values and decrease of exchangeable $\mathrm{Al}^{3+}$ contents (LOURENZI et al., 2016).

The highest soil $\mathrm{K}$ content was obtained in the combined oilseed radish (OR) and barley treatment, followed by the rye and oilseed radish treatments. (Table 1). This can probably be explained by the higher shoot dry mass produced by these species when intercropped (SOUZA et al., 2019), as compared to the other single-crop treatments. An abundance of plant tissue stimulates $\mathrm{K}$ accumulation 
in the soil (BASSEGIO et al., 2015). Oilseed radish also stands out as a nutrient-cycling crop, with rapid return to soils (LIMA et al., 2007). After the deposition of plant residues on the soil surface, $\mathrm{K}$ is quickly released, maintaining or even increasing its content in the soil (BASSEGIO et al., 2015; OLIVEIRA et al., 2016).

There were differences in microbial biomass (MBC) only among sampling times (Figure 2a). The highest values of MBC were observed in June, followed by the samplings from November and December (Figure 2a). In June, cover crops were collected 60 days after sowing (60 DAS) and were in different phenological stages. According to CZELUSNIAK et al. (2012), metabolite production in plants varies according to their development, including leaf development, emergence of new organs, biochemical, physiological, and ecological and evolutionary processes. OR plants were in the early stage of vegetative development, as they bloom 7080 days after emergence, while barley and rye, which have shorter cycles, were in the stem elongation stage (SOUZA et al., 2019). Therefore, the species were probably producing high rates of root exudate during this period, a carbon source for microorganisms (GARCIA et al., 2005). In the December sampling, the soil was still covered with some winter crop residues at different stages of decomposition. That, coupled with high temperatures and humidity, may have stimulated microbial biomass. Intermediate values of MBC occurred in July and November (Figure 2a). The MBC had low values in July (90 DAS) because at this stage cover plants are closer to the end of their cycle, having reduced metabolic activity in the root system. At this time, there was probably a reduction in root exudates, coupled with low temperatures and high rainfall (Figure 1), characteristic of mid-winter. Conversely, the values from November must be linked to the increased temperatures in late spring, as well as the influence of the remaining residues of winter cover plants. The lowest values of MBC were observed in August (Figure 2a). That sampling was done at the beginning of the onion cycle, in soil form recently transplanted seedlings, after the rolling of the cover crops. At such time onion growth was slow, which resulted in low amounts of organic matter as carbon source for soil microorganisms. The general mean of all treatments ( $286 \mu \mathrm{g} \mathrm{C} \mathrm{g}^{-1}$ dry soil) is in accordance with results reported in no-tillage systems (KASCHUK et al., 2010; SILVA et al., 2007).

Basal respiration also had significant differences only among sampling times (Figure $2 b$ ), with no interaction between treatments and sampling times. The value for June was higher than those of all other sampling times. One possible reason is rhizodeposition by the cover crops and spontaneous plants. Rhizodeposition is a source of available $\mathrm{C}$ for soil microbes, and that may increase soil microbial metabolic activity, thus enhancing decomposition of organic residues and mineralization of nutrients (BERTIN et al., 2003). For other sampling times, basal respiration rates were lower, as compared to the June sampling, possibly because the level of organic $\mathrm{C}$ in the soil was not sufficient to meet the demand by microorganisms (GARCIA et al., 2005). Therefore, most of the microbes were in inactive

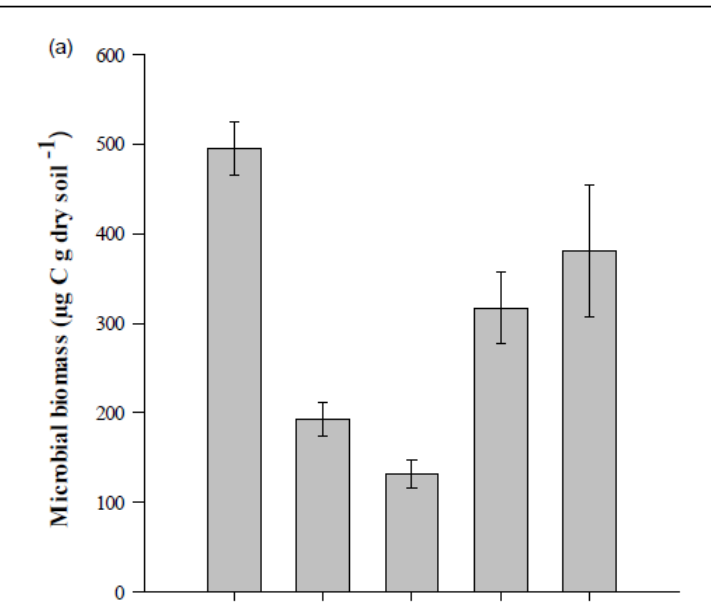

(b)

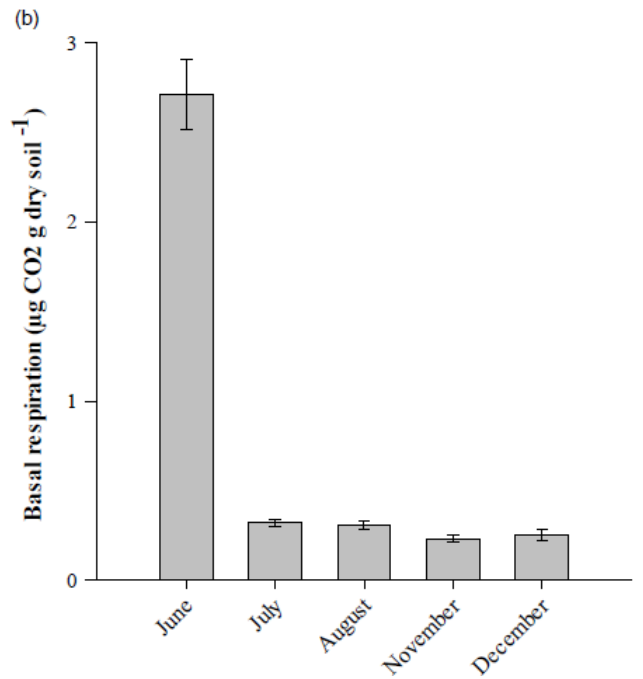

Figure 2 - Microbial biomass carbon (a) and basal respiration (b) in the $0-10 \mathrm{~cm}$ layer of a soil with onion grown over residues of winter cover crops in no-tillage system, in Santa Catarina, Southern Brazil, in June, July, August, November and December 2010. 
or latent forms, with little or no metabolic activity (MOREIRA \& SIQUEIRA, 2006). There was no significant differences among treatments, with a general mean of $0.76 \mu \mathrm{g} \mathrm{C}-\mathrm{CO}_{2} \mathrm{~g}^{-1}$ soil h $\mathrm{h}^{-1}$, which can be considered high, if compared to values reported in no-tillage systems in other regions of Brazil (SILVA et al., 2007; MERCANTE et al., 2008).

Significant differences in $\mathrm{qCO}_{2}$ occurred between sampling times (Table 2), with no interaction between treatments and sampling times, and no differences between treatments. The highest values in this ratio were observed in June, due to the rise in $\mathrm{MBC}$ and basal respiration, which were influenced by the presence of the cover crops, as previously discussed. Intermediate values occurred in the July and August samples, with a mean value of $5.74 \mu \mathrm{g}$ $\mathrm{C}-\mathrm{CO}_{2} \mathrm{mg}^{-1} \mathrm{MBC} \mathrm{h}^{-1}$. As production of exudates varies with plants age (BERTIN et al., 2003), cover crops did not produce the same amounts of exudates in July, because they were at the end of their cycles. Furthermore, for this sampling time there were lower values of $\mathrm{MBC}$ and lower respiration rates, as well as a decrease in $\mathrm{qCO}_{2}$. The intermediate results observed for the August sample were due to the recent rolling of the cover crops, with the resulting availability of $\mathrm{C}$ and nutrients from fresh plant residues. The lowest values are from in the November and December samples, with a mean value of $1.45 \mu \mathrm{g} \mathrm{C}-\mathrm{CO}_{2} \mathrm{mg}^{-1}$ $\mathrm{MBC} \mathrm{h}^{-1}$. In these cases, there was an increase in $\mathrm{MBC}$, but respiration was still low; therefore, causing a decrease in $\mathrm{qCO}_{2}$. The lower values reflect higher efficiency of the microbial biomass in the use of organic $\mathrm{C}$, meaning that less $\mathrm{C}$ is lost as $\mathrm{CO}_{2}$ through respiration and more $\mathrm{C}$ is incorporated into microbial cells (ANDERSON \& DOMSCH, 2010). No-tillage systems may provide more favorable conditions to microorganisms (MERCANTE et al., 2008), and lower values of $\mathrm{qCO}_{2}$ indicated environments that are under low or no stress (ANDERSON \& DOMSCH, 2010). FRANCHINI et al. (2007) demonstrated that Southern Brazil soils under conventional tillage had $\mathrm{qCO}_{2}$ values of $2.0 \mu \mathrm{g} \mathrm{C}-\mathrm{CO}_{2} \mathrm{mg}^{-1} \mathrm{MBC} \mathrm{h}^{-1}$, whilst in a no tillage system the values were $1.10 \mu \mathrm{g} \mathrm{C}-\mathrm{CO}_{2}$ $\mathrm{mg}^{-1} \mathrm{MBC} \mathrm{h}^{-1}$.

Enzyme activity assays showed differences in behavior of the different metabolic pathways assessed. In June, the activity of FDA enzyme in the control treatment was 7.9 and 2.1 times higher than in the treatments with barley and rye, respectively (Table 3 ). The OR + barley mix provided a $664 \%$ increase in FDA enzyme activity in comparison to barley alone. In December, FDA enzyme activity showed no statistical difference among the different treatments. We reported 23 more species of spontaneous plant in the control treatments than in the cover crop treatments, in the beginning, middle, and end of the onion cycle. This suggests that residues of these diverse spontaneous plants stimulate activity of this enzyme. Oilseed radish, either in monoculture or intercropped, had large dry matter production, which, coupled to its fast biomass degradation (LIMA et al., 2007), may explain the increase in FDA in treatments with that species. SÁNCHEZ-MONEDERO et al. (2008) observed that FDA activity is related to plant diversity, organic matter content, and state of decomposition, but it is little affected by environmental changes, such as temperature and humidity.

Urease activity varied between sampling times, with the highest values occurring in June (Table 3). The highest activity of this enzyme in June was due to the presence of cover plants with high metabolic activity (NEVINS et al., 2020). Rhizodeposition consists of organic acids, amino acids, sugars, and

Table 2 - Metabolic quocient $q \mathrm{CO}_{2}$ in five sampling times in the 0-10 $\mathrm{cm}$ layer of a soil with onion grown over residues of winter cover crops in no-tillage system in 2010, Santa Catarina, Southern Brazil.

\begin{tabular}{|c|c|}
\hline Sampling time & $\left(q \mathrm{CO}_{2}\right)$ \\
\hline & $\mu \mathrm{g} \mathrm{C}-\mathrm{CO}_{2} \mathrm{mg}^{-1} \mathrm{BMS} \mathrm{h}^{-1}$ \\
\hline June (Late Fall) & $11.0 \mathrm{a}^{*}$ \\
\hline July (Early Winter) & $6.0 \mathrm{~b}$ \\
\hline August (Winter) & $5.5 \mathrm{~b}$ \\
\hline November (Late Spring) & $1.6 \mathrm{c}$ \\
\hline December (Summer) & $1.3 \mathrm{c}$ \\
\hline
\end{tabular}

"Means followed by the same letter in each column do not differ by the Scott-Knott test $(\mathrm{P} \leq 0.05)$.

Ciência Rural, v.50, n.12, 2020. 
Table 3 - Enzyme activity in the 0-10 cm layer of a soil with onion grown over residues of winter cover crops in no-tillage system in 2010, Santa Catarina, Southern Brazil.

\begin{tabular}{|c|c|c|}
\hline Cover crop & June (late Fall) & December (Summer) \\
\hline \multicolumn{3}{|c|}{ 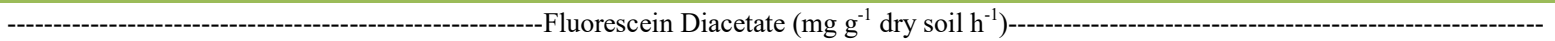 } \\
\hline Control (Fallow) & $104.0 \mathrm{a}^{*}$ & $71.5 \mathrm{a}$ \\
\hline Barley & $13.2 \mathrm{~b}$ & $50.9 \mathrm{a}$ \\
\hline Rye & $49.5 b$ & $58.9 \mathrm{a}$ \\
\hline Oilseed Radish (OR) & $64.4 \mathrm{a}$ & $67.6 \mathrm{a}$ \\
\hline $\mathrm{OR}+$ Rye & $73.8 \mathrm{a}$ & $77.8 \mathrm{a}$ \\
\hline $\mathrm{OR}+$ Barley & $101.8 \mathrm{a}$ & $61.7 \mathrm{a}$ \\
\hline \multicolumn{3}{|c|}{ 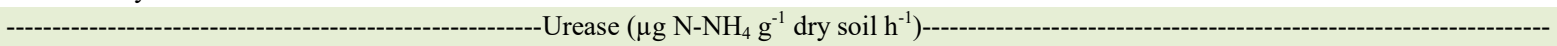 } \\
\hline Mean of all treatments & $4.37 \mathrm{~A}$ & $3.27 \mathrm{~B}$ \\
\hline \multicolumn{3}{|c|}{ 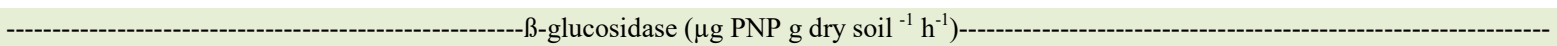 } \\
\hline Mean of all treatments & $87.2 \mathrm{~B}$ & $118.2 \mathrm{~A}$ \\
\hline
\end{tabular}

${ }^{*}$ Means followed by the same lower case letter in each column and the same capital letter in each line do not differ by the Scott-Knott test $(\mathrm{P} \leq 0.05)$.

vitamins, among others. Amino acids may decompose into organic molecules and urea (PAUL \& CLARK, 2007), which stimulates the production of the enzyme urease, which is affected by exudates (GARCIA et al., 2005; LANNA et al., 2010). In December, only residual cover crop residues remained on the soil, a factor leading to lower activity of the enzyme. Rye and barley, plants with high $\mathrm{C} / \mathrm{N}$ ratio, provide the soil a larger amount of $\mathrm{C}$ than of $\mathrm{N}$ for heterotrophic microorganisms; and consequently, they take longer to decompose amino acids in order to obtain nitrogen (PAUL \& CLARK, 2007).Conversely, in a study on the behavior of production of urease in the soil, MCCARTY et al. (1992) showed that the products derived from the assimilation of $\mathrm{NH}_{4}^{+} \mathrm{e} \mathrm{NO}_{3}^{-}$by microorganisms in the soil inhibit the production of the enzyme, which would explain the decrease of urease activity in the December sample. No differences were reported for urease activity among treatments, with average values of $3.8 \mu \mathrm{g} \mathrm{N}-\mathrm{NH}_{4} \mathrm{~g}^{-1}$ dry soil $\mathrm{h}^{-1}$, which is considered low. One possible explanation is that the activity of this enzyme was influenced by climate factors, such as temperature, or soil factors like $\mathrm{pH}$, aeration, texture and amount of organic C (LANNA et al., 2010).

There were differences among sampling times for $\beta$-glucosidase activity (Table 3 ). The highest values, in December, was 1.4 times higher than activity in June (Table 3). The high activity of this enzyme in December is related to the greater amount of organic residues incorporated to the soil, since higher levels of carbon in the soil lead to increased $\beta$-glucosidase activity (MOSCATELLI et al., 2012). This enzyme acts in the final step of cellulose decomposition (MATSUOKA et al., 2003), which may explain its increase in December, when the winter cover crop residues were in different stages of decomposition. The lowest values in June are due to the low amount of crop residues, which have been related to $\beta$-glucosidase activity (GARCIA et al., 2005). No significant differences in the activity of $\beta$-glucosidase were reported among treatments, with mean values of $103 \mu \mathrm{g}$ PNP g ${ }^{-1}$ dry soil $\mathrm{h}^{-1}$, results within the range of variation (52 to $783 \mu \mathrm{g} \mathrm{PNP} \mathrm{g}^{-1}$ dry soil $\mathrm{h}^{-1}$ ) of other studies carried out in no-tillage systems (NT) in Brazil (KASCHUK et al., 2010).

The Pearson correlation indexes showed complex interactions among the variables (Table 4). Basal respiration and urease had negative correlations with organic matter (-0.980 and -0.895$)$; $\mathrm{P}(-0.725$ and $-0.752) ; \mathrm{K}(-0.811$ e -0.694$) ; \mathrm{Mg}(-0.854$ and -0.778$)$ CEC (-0.779 and -0.771$)$. Conversely, those two variables had positive $(0.630$ and 0.718$)$ correlations with $\mathrm{pH}$. Respiration reflects the metabolic activity of microorganisms in the soil, which was enhanced by the degradation of winter cover crop residues. That process of mineralization is related to soil fertility, since nutrients may be used by microorganisms and ultimately made available to plants. The negative correlations have a relative value, since there were only significant differences between treatments in $\mathrm{pH}$ and exchangeable $\mathrm{K}$, but all the values are within levels which are considered satisfactory to growth of most plants (CQFSRS/SC, 2004). Activity of 
Table 4 - Pearson correlation indexes between chemical and biological variables in a soil under onion grown in no-tillage system in 2010, Santa Catarina, Brazil (mean of two sampling times).

\begin{tabular}{|c|c|c|c|c|c|c|c|}
\hline \multirow{2}{*}{ Variable } & Organic & $\mathrm{pH}$ & $\mathrm{pH}$ & & & & CEC \\
\hline & Matter & $\left(\mathrm{H}_{2} \mathrm{O}\right)$ & (SMP) & $\mathrm{P}$ & $\mathrm{K}$ & $\mathrm{Mg}$ & $(\mathrm{pH} 7.0)$ \\
\hline Microbial Biomass & $-0.535 \mathrm{~ns}$ & $0.187 \mathrm{~ns}$ & $0.180 \mathrm{~ns}$ & $-0.273 n s$ & $-0.466 \mathrm{~ns}$ & $-0.54 n s$ & $-0.387 n s$ \\
\hline Soil respiration & $-0.980^{*}$ & $0.630^{*}$ & $0.474 \mathrm{~ns}$ & $-0.725^{*}$ & $-0.811^{*}$ & $-0.854^{*}$ & $-0.779^{*}$ \\
\hline Urease activity & $-0.895^{*}$ & $0.718^{*}$ & $0.609^{*}$ & $-0.752^{*}$ & $-0.694^{*}$ & $-0.778^{*}$ & $-0.771^{*}$ \\
\hline ß-glucosidase activity & $0.790^{*}$ & $-0.209 \mathrm{~ns}$ & $-0.086 n s$ & $0.663^{*}$ & $0.848^{*}$ & $0.795^{*}$ & $0.683^{*}$ \\
\hline FDA activity & $-0.019 \mathrm{~ns}$ & $0.330 \mathrm{~ns}$ & $0.282 \mathrm{~ns}$ & $0.0571 \mathrm{~ns}$ & $0.287 \mathrm{~ns}$ & $0.185 \mathrm{~ns}$ & $0.227 \mathrm{~ns}$ \\
\hline
\end{tabular}

$\mathrm{ns}=$ not significant; ${ }^{*}=$ significant $(\mathrm{P} \leq 0.05)$

$\beta$-glucosidase presented high positive correlations ( $\mathrm{r}>0.66)$ with organic matter (0.790); $\mathrm{P}(0.663)$; K (0.848); $\mathrm{Mg}(0.795)$ and CEC (0.683). Those changes in the biological variables may be early indicators of changes in soil fertility, since this enzyme activity is related to the decomposition of organic matter and soil fertility (ROLDÁN et al., 2003).

Microbial biomass and FDA enzyme activity showed no significant correlation with the chemical attributes, demonstrating that this enzyme activity was not, in the short period of this study, sensitive enough to reflect changes in soil conditions. However,FDA activity was affected by cover crops (Table 3 ), with low values associated with use of grasses alone.

Onion yield was not affected by the treatments in this harvest, except for the control treatment, which presented a significantly lower value $\left(9.6 \mathrm{Mg} \mathrm{ha}^{-1}\right)$, as compared to all other treatments (general mean of $13.1 \mathrm{Mg} \mathrm{ha}^{-1}$ ) (Table 1 ), considering only commercially acceptable bulbs with diameter between $50 \mathrm{~mm}$ and $70 \mathrm{~mm}$ (class 3). That demonstrates the positive effect of growing and deposition of residues of soil cover crops in agroecological management without using pesticides and soluble mineral fertilizers on plant yield in the short term. However, the main benefits of no-tillage associated with cover crops are expected in the long term, especially in terms of soil and environmental quality. Those benefits will result from organic matter accumulation, greater microbial biomass and activity, which positively influence soil biological, chemical and physical attributes (GARCIA et al., 2005; MERCANTE et al., 2008).

Principal component analysis (PCA) for organic matter (OM), microbial biomass carbon (MBC), basal respiration (BR), metabolic quotient
$\left(\mathrm{qCO}_{2}\right)$, urease, $\beta$-glucosidase, and diacetate (FDA) hydrolysis activities demonstrated some trends in the complex relationship among the variables that were quantified (Figure 3). The relationship between the main component 1 (factor 1 ) and the main component 2 (factor 2) separated treatments into three groups. Factor 1 and Factor 2, together, explained $63.56 \%$ of the data variance. Factor 1 explained $37.68 \%$ of the variance and separated the control, rye, barley, oilseed radish, OR + rye and OR + barley treatments collected in June from the data from all other evaluation seasons. The microbiological attributes that most contributed to this separation were $\mathrm{MBC}$, $\mathrm{qCO}_{2}$, and BR. In June, higher levels of these biological attributes were observed, as compared to the other sampling times. That result reflected the influence of cover crops and weed diversity on soil chemical and biological quality. In agroecological notillage systems, weed management uses mechanical methods and pest and disease management uses natural or botanical products. That demonstrates the importance of including cover crops in agricultural systems, not only to promote nutrient cycling, but also to add $\mathrm{C}$ to the soil, which favors microbial activity (HUBBARD et al., 2013; RUEDA-AYALA et al., 2015). Furthermore, the presence of different weeds in the experimental area indicated their ability to cycle nutrients, as do the cover crops (OLIVEIRA et al., 2016).

Cluster analysis (represented by circles in Figure 3), carried out in conjunction with the PCA, also discriminated the collections performed in July and August and November and December. According to that analysis, Fluorescein diacetate (FDA) hydrolysis activity was the variable that most contributed to the separation of the treatments collected in July 


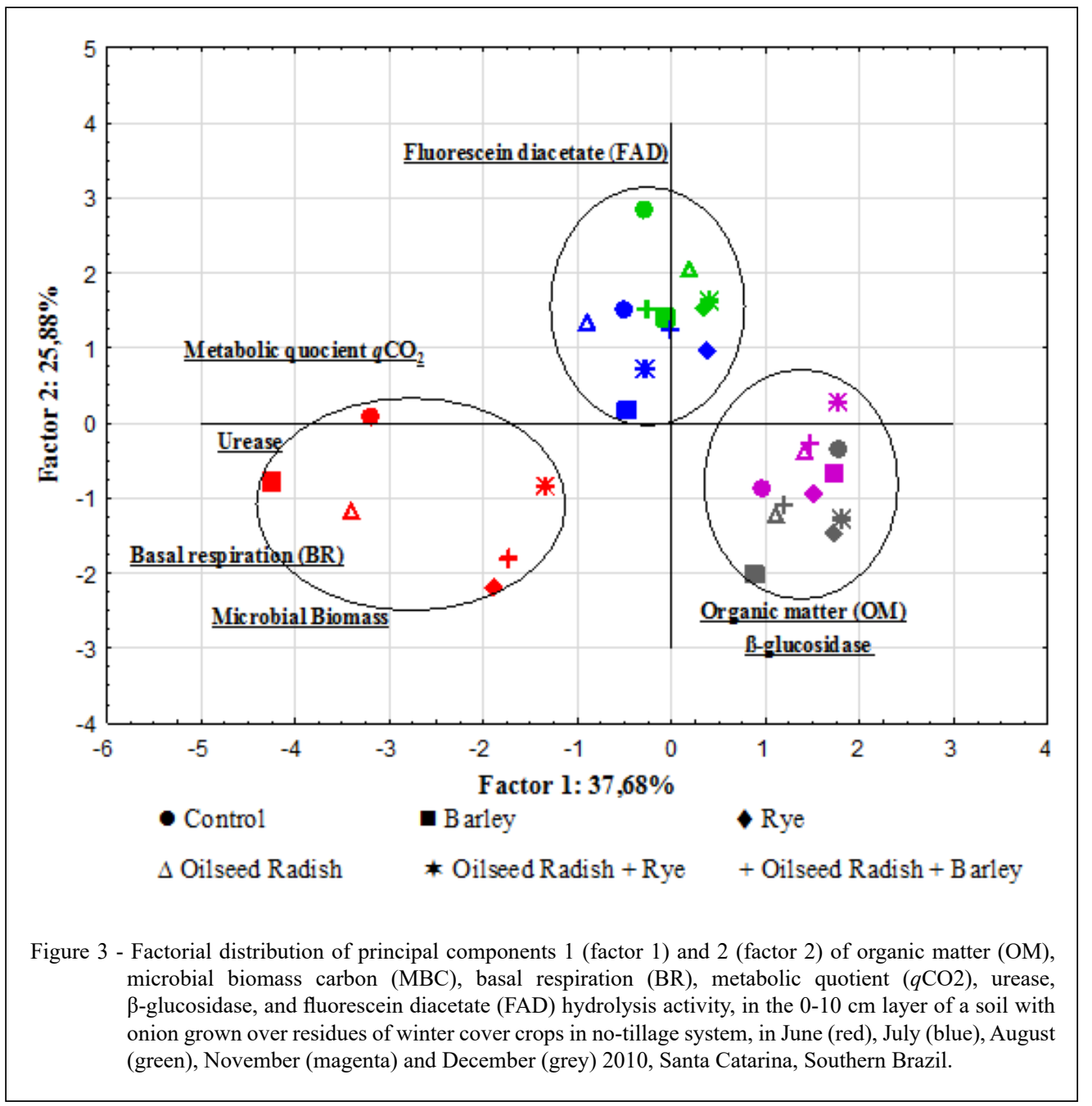

and August. In November and December, organic matter $(\mathrm{OM})$ and $\beta$-glucosidase activity had the most noticeable effect. The OM is a source of energy for microbial populations (MOSCATELLI et al., 2012), and the high activity of this enzyme in December is directly related to higher soil carbon levels found after the onion harvest in November and December, as compared to the levels found before onion seedling transplantation, in July and August. That is due to the gradual degradation of plant material along the onion cycle (OLIVEIRA et al., 2016). In this sense, mixes of cover crops favor soil quality. They provided soil cover, nutrient cycling, and slow nutrient release throughout the crop cycle, an important factor in conservation systems, as well as in agroecological transition, without the use of pesticides and soluble mineral fertilizers.

\section{CONCLUSION}

The use of winter cover crops and deposition of residues of barley, rye, and oilseed radish, single or intercropped, contribute to maintain and improve soil chemical attributes. FDA hydrolysis, which was lowered in single crops of barley and rye, was the only biological indicator affected by the cover crops. Soil microbial biomass, basal respiration, and urease and $\beta$-glucosidase activities did not vary among cover crops. Microbial activity varied throughout the onion cycle, and 60 days after sowing, all cover crop treatments had higher values of microbiological attributes than the control; microbial biomass, basal respiration; metabolic quotient $\left(\mathrm{qCO}_{2}\right)$ contributed the most for those results. 


\section{ACKNOWLEDGEMENTS}

This work was funded by Fundação de Apoio à Pesquisa Científica e Tecnológica do Estado de Santa Catarina (FAPESC), Coordenação de Aperfeiçoamento de Pessoal de Nível Superior - Brasil (CAPES) - Finance Code 001, and Conselho Nacional de Desenvolvimento Científico e Tecnológico (CNPq) (Edital $\mathrm{n}^{\circ} 58 \mathrm{MDA} / \mathrm{CNPq} 2010$ and Research Assistantships for CRFSS, JJC, and PEL). We thank the undergraduate students of the Laboratory of Water, Soil, and Plant Tissue Analysis, Rural Engineering Dept./CCA/Universidade Federal de Santa Catarina (UFSC), for their contribution to field and laboratory work.

\section{DECLARATION OF CONFLICT OF INTERESTS}

The authors declare no conflict of interest. The founding sponsors had no role in the design of the study; in the collection, analyses, or interpretation of data; in the writing of the manuscript, and in the decision to publish the results.

\section{AUTHORS' CONTRIBUTIONS}

All authors contributed to the manuscript.

\section{REFERENCES}

ANDERSON, T. H. \& DOMSCH, K. H. Soil microbial biomass The eco-physiological approach. Soil Biology and Biochemistry, v.42, p.2039-20435, 2010. Available from: <https://doi. org/10.1016/j.soilbio.2010.06.026>. Accessed: Mar. 18, 2019. doi: 10.1016/j.soilbio.2010.06.026

BASSEGIO, D. et al. Short-term effects of crop rotations on soil chemical properties under no-tillage condition. Australian Journal of Crop Science, v.9, p.49-54, 2015. Available from: $<$ http://www.cropj.com/ bassegio 91201549 54.pdf $>$. Accessed: Mar. 20, 2019.

BENINTENDE, S. M. et al. Soil microbiological indicators of soil quality in four rice rotations systems. Ecological Indicators, v.8, p.704-708, 2008. Available from: <https://doi.org/10.1016/j.ecolind.2007.12.004>. Accessed: Mar. 20, 2019. doi: 10.1016/j.ecolind.2007.12.004.

BERTIN, C. et al. The role of root exudates and allelochemicals in the rhizosphere. Plant Soil, v.256, p.67-83, 2003 Available from: <https://link.springer.com/article/10.1023\% 2FA\%3A102629.0508166>. Accessed: Sep. 10, 2019. doi: 10.1023/A:1026290508166.

COMISSÃO DE QUÍMICA E FERTILIDADE DO SOLO CQFSRS/SC. Manual de adubação e de calagem para os Estados de Rio Grande do sul e de Santa Catarina. 10 ed. Porto Alegre, Brasil. 2004. 400p.

CZELUSNIAK, K. E. et al. Pharmacobotany, phytochemistry and pharmacology of guaco: a review considering Mikania glomerata Sprengel e Mikania laevigata Sch. Bip. ex Baker. Revista Brasileira Plantas Medicinais, v.14, p.400-409, 2012. Available from: $<$ http://www.scielo.br/pdf/rbpm/v14n2/22.pdf $>$. Accessed: Oct. 20, 2019. doi: 10.1590/S1516-05722012000200022.

DICK, R. P. et al. Soil enzyme activities and biodiversity measurements as integrative microbiological indicators. In:
DORAN, J. W.; JONES, A. J., eds. Handbook of methods for assessing soil quality. Madison, Soil Science Society of America, 1996. p.247-272.

EPAGRI. Onion production system: Santa Catarina $\left(4^{\mathrm{a}}\right.$. revisão). Florianópolis: EPAGRI, 2013. 106p.

FRANCHINI, J. C. et al. Microbiological parameters as indicators of soil quality under various soil management and crop rotation systems in southern Brazil. Soil Tillage Research, v.92, p.18-29, 2007. Available from: <https://doi.org/10.1016/j.still.2005.12.010>. Accessed: Oct. 25, 2019. doi: 10.1016/j.still.2005.12.010.

GARCIA, C. et al. Ability of different plant species to promote microbiological processes in semiarid soil. Geoderma, v.124, p.193-202, 2005. Available from: < https://doi.org/10.1016/j. geoderma.2004.04.013>. Accessed: Oct. 07, 2019. doi: 10.1016/j. geoderma.2004.04.013

HAN, J. et al. "Data Transformation and Data Discretization" In: Data Mining: Concepts and Techniques. Elsevier. 2011. p.111-118.

HUBBARD, R. K. et al. Effects of cover crop systems on soil physical properties and carbon/nitrogen relationships in the coastal plain of southeastern USA. Soil \& Tillage Research, v.126, p.276-283, 2013. Available from: $<$ https://doi.org/10.1016/j.still.2012.07.009>. Accessed: Oct. 15, 2019. doi: 10.1016/j.still.2012.07.009.

JENKINSON, D. S. \& POWLSON, D. S. The effect of biocidal treatments on metabolism in soil. I Fumigation with chloroform. Soil Biology and Biochemistry, v.8, p.167-177, 1976. Available from: $<$ https://doi.org/10.1016/0038-0717(76)90001-8>. Accessed: Oct. 18, 2019. doi: 10.1016/0038-0717(76)90001-8.

KASCHUK, G. et al. Three decades of soil microbial biomass studies in Brazilian ecosystems: Lessons learned about soil quality and indications for improving sustainability. Soil Biology and Biochemistry, v.42, p.1-13, 2010. Available from: <https://doi. org/10.1016/j.soilbio.2009.08.020>. Accessed: Oct. 20, 2019. doi: 10.1016/j.soilbio.2009.08.020.

KÖPPEN, W.; GEIGER, R. (Eds): Handbuch der Klimatologie. Berlin: Gebrüder Bornträger, 1936. Banda 1, Parte C, p.1-44.

LANNA, A. C. et al. Urease activity in the soil with beans influenced by vegetation cover and planting systems. Revista Brasileira de Ciência do Solo, v.34, p.1933-1939, 2010. Available from: <http:/ dx.doi.org/10.1590/S0100-06832010000600018>. Accessed: Jun. 18, 2019. doi: 10.1590/S0100-06832010000600018.

LIMA, J. D. et al. Behavior the Raphanus sativus L. and Raphanus raphanistrum L. as green manure. Pesquisa Agropecuária Tropical, v.1, p.60-63, 2007. Available from: <https://www. revistas.ufg.br/pat/article/view/1871>. Accessed: Oct. 20, 2019. doi: $10.5216 /$ pat.v37i1.1871.

LOSS, A. et al. Total organic carbon and soil aggregation in an onion agroecological and conventional no-tillage system. Revista Brasileira de Ciência do Solo, v.39, p.1212-1224, 2015. Available from: <http://dx.doi.org/10.1 590/01000683rbcs20140718>. Accessed: Oct. 29, 2019. doi: $10.1590 / 01000683 \mathrm{rbcs} 20140718$.

LOURENZI, C. R. et al. Latossolo chemical attributes after successive applications of organic compounds from pig slurry. 
Pesquisa Agropecuária Brasileira, (Online), v.51, p.233-242, 2016. Available from: $<$ https://www.scielo.br/scielo.php?pid=S0100204X2016000300233\&script=sci_arttext>. Accessed: Oct. 29, 2019. doi: 10.1590/S0100-204X2016000300005.

MARINARI, S.; MANCINELLI, R.; CAMPIGLIA, E.; GREGO, S. Chemical and biological indicators of soil quality in organic and conventional farming systems in Central Italy. Ecological Indicators, v.6, p.701-711, 2006

MARTINEZ-SALGADO M, M. et al., Biological soil quality indicators: a review. In: Méndez-Vilas, A. (Ed.). Current Research, Tecnologhy and Education Topics in Applied Microbiology and Microbial Technology. 2ed. Formatex Research Center: Badajoz. p.319-328, 2010.

MATSUOKA, M. et al. Microbial biomass and enzymatic activity in soils under native vegetation and annual and perennial agricultural systems in the region of Primavera do Leste (MT). Revista Brasileira de Ciência do Solo, v.27, p.425-433, 2003. Available from: <http:// dx.doi.org/10.1590/S0100-06832003000300004>. Accessed: Oct. 20, 2019. doi: 10.1590/S0100-06832003000300004.

McCARTY, G. W. et al. Regulation of Urease production in soil by microbial assimilation of nitrogen. Biology and Fertility of Soils, v.12, p.261-264, 1992. Available from: <https://link.springer.com article/10.1007/BF00336041>. Accessed: Oct. 20, 2019. doi $10.1007 / \mathrm{BF} 00336041$

MERCANTE, F. M. et al. Microbial biomass, in a Argissolo Vermelho, in different cover crops, in an area cultivated with cassava. Acta Scientiarum. Agronomy, v.34, p.479-485, 2008. Available from: $<$ http://dx.doi.org/10.4025/actasciagron.v30i4.5301>. Accessed: Jul. 20, 2019. doi: 10.4025/actasciagron.v30i4.5301.

MIGLIORINI, P., WEZEL,A. Converging and diverging principles and practices of organic agriculture regulations and agroecology. A review. Agron. Sustain. v.37, 63, 2017. Available from: $<$ https:// link.springer.com/content/pdf/10.1007/s13593-017-0472-4.pdf>. Accessed: Jul. 20, 2020. doi: 10.1007/s13593-017-0472-4.

MONEGAT, C. Plantas de cobertura do solo: características e manejo em pequenas propriedades. Chapecó, Santa Catarina Editora do Autor, 1991. 336p.

MOREIRA, F. M. S. \& SIQUEIRA, J. O. Microbiologia e bioquímica do solo. 2. ed. Lavras, UFL, 2006. 729p.

MOSCATELLI, M. C. et al. $\beta$-glucosidase kinetic parameters as indicators of soil quality under conventional and organic cropping systems applying two analytical approaches. Ecological Indicators, v.13, p.322-327, 2012. Available from: <https://doi. org/10.1016/j.ecolind.2011.06.031>. Accessed: Oct. 22, 2019. doi: 10.1016/j.ecolind.2011.06.031.

NEVINS et al. The synchrony of cover crop decomposition, enzyme activity, and nitrogen availability in a corn agroecosystem in the Midwest United States. Soil Till. Res., v.197, 2020. Available from: <https://doi.org/10.1016/j.still.2019.104518>. Accessed: Jun. 8, 2020. doi: 10.1016/j.still.2019.104518

OLIVEIRA, R. A. et al. Cover crops effects on Soil Chemical Properties and Onion Yield. Revista Brasileira Ciência do Solo, v.40, p.1-17, 2016. Available from: <http://dx.doi.org/10 $.1590 / 18069657 \mathrm{rbcs} 20150099>$. Accessed: Oct. 22, 2019. doi: $10.1590 / 18069657 \mathrm{rbcs} 20150099$.
PANACHUKI, E. et al. Perdas de solo e de água e infiltração de água em Latossolo vermelho sob sistemas de manejo. Revista Brasileira de Ciência do Solo, v.35, n.5, p.1777-1786, 2011. Available from: <http://dx.doi.org/10.1590/S0100-06832011000500032>. Accessed: Oct. 29, 2019. doi: 10.1590/S0100-06832011000500032.

PAUL, E.A. \& CLARK, F. E. Soil microbiology and biochemistry. $3^{\text {th }}$ ed. USA, Academic Press Publications, 2007. 462p.

RAMOS, M. E. et al. Cover crops under different managements vs. frequent tillage in almond orchards in semiarid conditions: Effects on soil quality. Applied Soil Ecology, v.44, p.6-14, 2010. Available from: <https://doi.org/10.1016/j.apsoil.2009.08.005> Accessed: Oct. 22, 2019. doi: 10.1016/j.apsoil.2009.08.005.

ROLDÁN, A. et al. No-tillage, crop residue additions, and legume cover cropping effects on soil quality characteristics under maize in Patzcuaro watershed (Mexico). Soil and Tillage Research, v.72, p.65-73, 2003. Available from: <https://doi.org/10.1016/S0167-1987(03)000515>. Accessed: Oct. 22, 2019. doi: 10.1016/S0167-1987(03)00051-5.

RUEDA-AYALA, V.; GERHARDS, O. J. R. Investigation of biochemical and competitive effects of cover crops on crops and weeds. Crop Protection, v.71, p.79-87, 2015. Available from: $<$ https://doi.org/10.1016/j.cropro.2015.01.023>. Accessed: Jun. 15, 2019. doi: 10.1016/j.cropro.2015.01.023.

SÁNCHEZ-MONEDERO, M. A. et al. Fluorescein diacetate hydrolysis, respiration and microbial biomass in freshly amended soils. Biology and Fertility of Soils, v.44, p.885-890, 2008. Available from: $\quad<$ https://link.springer.com/article/10.1007/s00374-007-0263-1>. Accessed: Oct. 20, 2019. doi: 10.1007/s00374-007-0263-1.

SILVA, M. B. et al. Atributos biológicos do solo sob influência da cobertura vegetal e do sistema de manejo. Pesquisa Agropecuária Brasileira, v.42, p.1755-1761, 2007. Available from: <http://www. scielo.br/pdf/pab/v42n12/a13v4212.pdf>. Accessed: Oct. 18, 2019.

SOIL SURVEY STAFF. 2010. Keys to Soil Taxonomy. 11th Edition, USDA-NRCS, Washington DC.

SOUZA, M. et al. Phenolic Compounds with Allelopathic Potential of Secale cereale L. and Raphanus sativus L. Grown Under an Agroecological No-Tillage System. Planta Daninha, v.37, p.1-12. 2019. Available from: $<$ https:/www.scielo.br/pdf/pd/v37/0100-8358-PD-37-e019193842.pdf>. Accessed: Oct. 18, 2019. doi: 10.1590/s0100-83582019370100090.

TABATABAI, M. A. \& BREMNER, J. M. Assay of urease activity in soil. Soil Biology and Biochemistry, v.4, p.479-487, 1972. Available from: <https://doi.org/10.1016/0038-0717(72)900648>. Accessed: Mar. 18, 2019. doi: 10.1016/0038-0717(72)90064-8.

TEDESCO, M. J. et al. Análises de solo, plantas e outros materiais. 2. ed. Porto Alegre, Departamento de Solos, UFRGS. 1995. 174p. (Boletim Técnico 5).

VANCE, E. D. et al. Microbial biomass measurements in fores soils: the use chloroform fumigation-incubation method in strongly acid soils. Soil Biology and Biochemistry, v.19, p.697-702, 1987. Available from: $<$ https://doi.org/10.1016/0038-0717(87)90051-4>. Accessed: Oct. 24, 2019. doi: 10.1016/0038-0717(87)90051-4.

WEZEL, A. et al. Agroecological practices for sustainable agriculture. A Review. Agron. Sustain. Dev., v.34, p.1-20, 2014. Available from: <https://doi.org/10.1007/s13593-013-0180-7>. Accessed: Jun. 24, 2020. doi: 10.1007/s13593-013-0180-7. 